\title{
Fandom and Risk Perceptions of Olympic Tourists
}

Perceptions that travel to globally high profile events and destinations can be a risky activity has become more prevalent in recent years in response to various disastrous global incidents; some linked to major sports events such as the terrorist attacks at the Boston Marathon in April 2013 or at the Stade de France stadium in Paris in November 2015. In this current climate of perceived risk and uncertainty surrounding travel, and with specific relevance to mega sport events, this research note reviews the risk perceptions of Olympic tourists who travelled to Brazil for the 2016 Rio Games.

Weed (2008:22) defines Olympic tourism as "tourism behaviour motivated or generated by Olympic-related activities". This note explores the construct of Olympic 'fandom', that is the Olympic tourist's attachment to and selfidentification with the games (Kirkup, 2012). Fandom is explored in terms of its influence on risk perceptions and worry, towards the threat of terrorism, crime, and the Zika Virus. We determine with whom Olympic tourists place their trust, (event versus host destination), in terms of ensuring their safety and security, which may in turn also inform thinking on the nature of individual resilience in the future.

Perceived risk is recognized as influencing destination choice and travel decisions. Individuals may perceive a number of risk types, ranging from fear of involvement in a terrorist incident to experiencing poor value for money (Fuchs and Reichel, 2011; Roehl and Fesenmaier, 1992). However, the nature and significance of these risks might differ from one destination or situation to another. Larson, Brun and Ogaard (2009) attempt to better understand people's risk related judgements of situations by introducing the concept of worry to tourism. They distinguish worry from risk; arguing that subjective risk is the intuitive individual perceptions of the probability that an incident may occur, while worry is a negative emotion that entails uncontrollable chains of thought in response to uncertainty relating to possible events. We concede therefore that when reviewing Olympic tourists' sentiment towards their safety and security whilst attending the Games, it is advisable to measure not only the extent to which they perceive risk but also how much the threat of that risk worries them.

The increasing number of terrorism incidents and other crises has led to an increased focus on risk and safety at multiple levels. The tourism industry in particular is constantly looking for mitigation strategies to prevent major disruptions to tourism flows and sustain economically viable tourism numbers. According to Walters, Mair \& Ritchie (2014) loyalty and destination attachment may reduce concern among tourists with regards to visiting a destination that has experienced crises or disasters. Previous research has also revealed that past experience will reduce risk perceptions towards high risk destinations (see for example: Sharifpour, Walters, Ritchie and Winter, 2013: Lepp and Gibson, 2008). In the sports event context, this research seeks to explore the interplay between an Olympic tourists' attachment to and self-identification with the Olympic Games, defined in this research note as 'fandom' and their risk perceptions and worries in relation to a variety of media induced concerns leading up to the Rio 
Games, i.e. terrorism, Zika Virus and crime levels. Research in this area is somewhat limited, with Qi, Gibson and Zhang (2009) being one of the few to examine the relationship between risk perceptions and travel intentions for the 2008 Beijing Olympic Games. The current study extends Qi et al's findings by exploring the risk related concerns of actual versus potential Olympic tourists.

\section{Method}

Data collection for this exploratory study occurred during the Rio Olympic Games in August 2016 in Brazil. The survey included items to measure Olympic tourists risk perceptions and their degree of worry relating to the threat of terrorism, the Zika Virus, and crime). Risk-taking propensity and their degree of attachment to the Olympics, as sports fans (i.e. fandom), were also assessed (Kirkup, 2012). Information pertaining to demographic background and past travel behaviour was collected to determine the explanatory power of these defining variables. A further four items were created by the researchers to explore the extent of trust Olympic fans have in the Organising Committee for the Olympic Games (OCOG) and the host destination security officials, and the responsibility they attribute to these stakeholders. The questionnaire was limited to one page to reduce the time commitment for respondents and administered outside Rio's Olympic sites. A total of 102 responses were collected.

\section{Results}

An initial analysis of risk perceptions amongst Olympic tourists indicated no significant differences in terms of gender and age, no differences between attendees who had previously attended the Olympic Games, and no differences between those who were first time verses repeat visitors to the host city, Rio. Possible explanation for this insignificance could be that for the majority of the Olympic tourists, $(80.4 \%)$, it was their first trip to Rio, and $92.2 \%$ were in Rio specifically for the Games. Interestingly, close to 70\% (69.3\%) had previously attended the Olympics, and it is likely there is a relationship between the previous 2012 London Games and the high proportion of UK attendees (59.8\%) in this sample. The descriptive statistics highlighted that $81.4 \%$ of the respondents originated from the UK (59.8\%), Europe $(10.8 \%)$, or the USA $(10.8 \%)$.

A factor analysis revealed fandom to be a unidimensional construct accounting for $69.4 \%$ of the variance (Chronbach's alpha $=.88$ ). On a likert scale of $1-7$, the mean score for fandom amongst Olympic tourists was 5.68 and over $75 \%$ of the sample indicated a strong attachment to the event, consistent with the findings of Kirkup's (2012) study at the 2008 Beijing Games. With respect to this preliminary research's focal point of exploring the relationship between Olympic fandom, risk and worry, a series of independent t-tests (see Table 1) revealed that those Olympic tourists who identified as being avid fans of the Olympic Games expressed a significantly higher level of worry about being a victim of crime ( $M=4.66$ vs 2.42$)$ and contracting the Zika Virus ( $M=2.42$ vs 1.68$)$ whilst in Rio for the Games than those who did not score highly on the fandom scale. 


\begin{tabular}{|l|c|c|c|c|c|c|c|}
\hline \multicolumn{7}{|c|}{ Table 1: Differences in Risk Perception and Worry and Fandom } \\
\cline { 2 - 9 } & & & \multicolumn{7}{c|}{$\begin{array}{c}\text { t-test for Equality of Means } \\
\text { Item }\end{array}$} & $\mathrm{t}$ & $\mathrm{df}$ & $\begin{array}{c}\text { Sig. } \\
\text { tailed) }\end{array}$ & $\begin{array}{c}\text { Mean } \\
\text { Difference }\end{array}$ & $\begin{array}{c}\text { Std. Error } \\
\text { Difference }\end{array}$ & $\begin{array}{c}95 \% \text { Confidence Interval of the } \\
\text { Difference }\end{array}$ \\
\cline { 2 - 9 } & Lower & Upper \\
\hline I am worried about the threat of terrorism & 1.901 & 98 & .060 & .711 & .374 & -.031 & 1.453 \\
\hline $\begin{array}{l}\text { I am worried about contracting the Zika } \\
\text { Virus }\end{array}$ & $3.004^{*}$ & 98 & .004 & .741 & .312 & .122 & 1.361 \\
\hline $\begin{array}{l}\text { I am worried about being a victim of } \\
\text { crime while in Rio }\end{array}$ & $2.128^{*}$ & 96 & .036 & .853 & .401 & .057 & 1.648 \\
\hline $\begin{array}{l}\text { I believe the risk of terrorism in Rio at } \\
\text { the current time is high }\end{array}$ & .733 & 98 & .465 & .282 & .385 & -.481 & 1.045 \\
\hline $\begin{array}{l}\text { I believe I have a high risk of contracting } \\
\text { the Zika Virus }\end{array}$ & 1.715 & 97 & .090 & .558 & .326 & -.088 & 1.205 \\
\hline $\begin{array}{l}\text { The Olympic games organisers will } \\
\text { ensure I am safe from harm while I am } \\
\text { at the games }\end{array}$ & 3.152 & 98 & .002 & 1.437 & .456 & .532 & 2.342 \\
\hline $\begin{array}{l}\text { Rio security officials will ensure I am } \\
\text { safe from harm while visiting the city }\end{array}$ & 2.406 & 98 & .018 & .975 & .405 & .171 & 1.778 \\
$\begin{array}{l}\text { It is the Olympic games' responsibility } \\
\text { to keep attendees safe }\end{array}$ & 1.870 & 98 & .064 & .765 & .409 & -.047 & 1.577 \\
\hline $\begin{array}{l}\text { It is the host destination's } \\
\text { responsibility to keep attendees safe }\end{array}$ & 2.708 & 97 & .008 & 1.058 & .391 & .283 & 1.834 \\
\hline
\end{tabular}

The results of further t-tests (see Table 1) provided possible explanation for this finding that while avid fans were more likely to worry about contracting the Zika Virus and being a victim of crime, they still attended the Games. When it came to the level of trust tourists placed on the OCOG and the host destination to keep them safe from harm, avid fans placed more trust in their Olympic hosts ( $M=4.81$ vs 3.41) and the destination security officials (4.84 vs 3.87) than those who did not present as avid fans of the Games. The implications for future host cities would indicate that Olympic fans with a strong attachment for the Games are a resilient group of travellers who have expectations from the host city and the OCOG to maintain their safety; however if these expectations are ensured, then their willingness to travel and their resilience to global security concerns would appear to be mitigated against. Despite there being no significant difference between avid and moderate fans in terms of their concerns regarding a terrorist attack, a linear regression analysis revealed that generally, the Olympic tourist's belief that Rio's security organisations and officials will maintain their safety can potentially mitigate the concerns they have related to terrorism. Respondents trust in Games officials and the host destination to keep them safe explained $11 \%$ of the variance in respondent concern about terrorism, $\mathrm{R}^{2}=11.2, F(4,93)$ $=2.923, \mathrm{p}<.05$. Observation of the standardised regression coefficients further revealed that Olympic tourists' trust in destination security officials $(\beta=-.387$, $\mathrm{p}<.05$ ) and the responsibility they place on the host destination to keep them safe from harm $(\beta=.293, p<.05)$ are significant predictors of the worry they are likely to experience in relation to the threat of terrorism.

Overall, the data demonstrates that the level of fandom (be they avid or non-avid fans) can mitigate concerns and worries relating to safety and security at the 
Games. Trust in destination security officials can also help offset risk perceptions and concerns relating to attendance at mega sports events like the Olympic Games. In summary, developing a deeper understanding and awareness of Olympic tourists' perceptions of risk associated with travelling to sport mega events should be far better leveraged amongst Olympic Games stakeholders including host cities, OCOGs, and the IOC (International Olympic Committee) to develop suitable strategies and tactics to reassure travelling sports fans and to send optimal communication messages, in order to assure continued demand in future times of crisis amongst a relatively resilient segment of the sport tourism market. Following on from this, there is also a need to research more deeply the relationship and assumptions between individual and organisational resilience when preparing for future Olympic Games.

\section{References}

Fuchs, G., \& Reichel, A. (2011). An exploratory inquiry into destination risk perceptions and risk reduction strategies of first time vs. repeat visitors to a highly volatile destination. Tourism Management, 32(2), 266-276.

Kirkup, N. (2012) Olympic tourists: seeking a sense of belonging and the construction of social identities. In Shipway, R. and Fyall, A. (eds). International Sports events: Impacts, Experiences and Identities. Routledge: London.

Lepp, A., \& Gibson, H. (2003). Tourist roles, perceived risk and international tourism. Annals of tourism research, 30(3), 606-624.

doi:http://dx.doi.org/10.1016/S0160-7383(03)00024-0

Larsen, S., Brun, W., \& Øgaard, T. (2009). What tourists worry about-Construction of a scale measuring tourist worries. Tourism Management, 30(2), 260-265.

Qi, C., Gibson, H.J., \& Zhang, J.J. (2009). Perceptions of Risk and Travel Intentions: The Case of China and the Beijing Olympic Games. Journal of Sport and Tourism, 14 (1), 43-67.

Roehl, W. S., \& Fesenmaier, D. R. (1992). Risk perceptions and pleasure travel: An exploratory analysis. Journal of Travel Research, 30(4), 17-26.

Walters, G., Mair, J., \& Ritchie, B. (2015). Understanding the tourist's response to natural disasters: The case of the 2011 Queensland floods. Journal of Vacation Marketing, 21(1), 101-113.

Weed, M. (2008) Olympic tourism. Oxford: Elsevier. 